\title{
Prognostic value of expression of nuclear factor kappa-B/p65 in non-GCB DLBCL patients
}

\author{
Jing Wang ${ }^{1, *}$, Min Zhou ${ }^{1, *}$, Qi-Guo Zhang ${ }^{1, *}$, Jingyan $X \mathbf{u}^{1, *}$, Tong Lin ${ }^{1}$, Rong-Fu Zhou ${ }^{1}$, \\ Juan Li ${ }^{1}$, Yong-Gong Yang ${ }^{1}$, Bing Chen ${ }^{1}$, Jian Ouyang ${ }^{1}$ \\ ${ }^{1}$ Department of Hematology, The Affiliated DrumTower Hospital of Nanjing University Medical School, Nanjing 210008, \\ Jiangsu, PR China \\ *These authors contributed equally to this work and should be considered as co-first authors \\ Correspondence to: Jian Ouyang, email: ouyang211@hotmail.com \\ Bing Chen, email: chenbing2004@126.com \\ Keywords: diffuse large B-cell lymphoma, p65, NF-KB, international prognostic index \\ Received: July 25, $2016 \quad$ Accepted: November 22, 2016 \\ Published: December 26, 2016
}

\section{ABSTRACT}

Purpose: We estimated the expression of nuclear factor kappa B/p65 in nongerminal center B-cell-like subtype diffuse large B-cell lymphoma, to investigate its relationship to clinicopathological features, and to further evaluate its prognostic value and clarify its impact on survival.

Results: Among the 49 patients enrolled in this study, $14(28.6 \%)$ had positive p65 expression. The negative p65 group had significantly better survival compared to the positive p65 group in terms of both the 3-year estimated OS (91.2\% vs. $39.3 \%$, $p=0.003)$ and PFS (75.6\% vs. $26.5 \%, p=0.002)$. In patients with 4 or more risk factors, p65 was an independent prognostic factor of OS (HR 5.99, 95\%CI=1.3925.75, $p=0.016$ ) and PFS (HR 4.01, 95\%CI =1.15-14.00, $p=0.029$ ).

Materials and Methods: The expression of the NF-kB/p65 protein was deteremined by immunohistochemistry in 49 non-GCB DLBCL. Survival was assessed by the KaplanMeier method and Cox multivariate analysis. The median patient follow-up period was 24 months.

Conclusions: The expression of NF-KB/p65 has prognostic value in high risk nonGCB DLBCL, and it is a suitable target for the development of new therapies.

\section{INTRODUCTION}

Diffuse large B-cell lymphoma (DLBCL) is the most common non-Hodgkin lymphoma (NHL), accounting for $25-35 \%$ of all new non-Hodgkin lymphoma diagnoses made globally each year [1]. Although gene expression profiling (GEP) has identified distinct DLBCL subtypes based on the differential expression of genes involved in B-cell development [28], it is not practical to perform GEP at most clinical institutions. Several groups have attempted to use immunohistochemistry (IHC) to distinguish between the germinal center B-cell (GCB) and non-germinal center B-cell (non-GCB) subtypes of DLBCL. Hans et al. used IHC for CD10, bcl-6 and MUM-1 to subdivide DLBCL into GCB and non-GCB subtypes [9]. The Hans classifier showed a concordance with the GEP gold standard of
71-93\%[9-11]. The standard frontline treatment for patients with DLBCL, established over a decade ago, is rituximab, cyclophosphamide, doxorubicin, vincristine, and prednisone (R-CHOP) immunochemotherapy [12]. IHC-based cell of origin (COO) is a strong prognostic biomarker for identifying patient groups with substantially different outcomes following R-CHOP $[7,8,13-16]$. IHC algorithm had strong prognostic power matching that of GEP in DLBCL patients [16]. The use of an IHC algorithm has been widely adopted diagnostically, and has been incorporated into the British Committee on Standards in Haematology (BCSH) guidelines for lymphoma.

The nuclear factor kappa B (NF- $\kappa$ B) family of transcription factors control genes implicated in B-cell activation, proliferation and resistance to apoptosis [17]. In normal B cells, NF- $\kappa B$ activity was critical for B-cell development and survival [18]. NF- $\mathrm{B}$ was 
constitutively activated in non-GCB DLBCL [19-20] and may be associated with drug resistance and a poorer prognosis [21]. Dimers of NF- $\kappa \mathrm{B}$ family members (p50/105, p52/100, p65/RelA, p65/RelB and p65/c-Rel) mediated NF- $\kappa \mathrm{B}$-dependent transcriptional activities, and these molecules were regulated by members of the I $\kappa \mathrm{B}$ family of inhibitors, which binded to NF$\kappa \mathrm{B}$ dimers and retained them in the cytoplasm [22]. Many downstream genes, which were involved in the regulation of cell survival, cell cycle distribution, and apoptosis, were proved to be transactivated by the p 65 subunit of NF- $\kappa \mathrm{B}$ [23].

In this study of non-GCB DLBCL patients, the relationship between the expression of $\mathrm{NF}-\kappa \mathrm{B} / \mathrm{p} 65$ protein and clinicopathological parameters, and the prognostic value of $\mathrm{NF}-\kappa \mathrm{B} / \mathrm{p} 65$ protein expression were explored.

\section{RESULTS}

\section{Patients}

The median age of the patients was 59 years (range 18-77 years), with 23 women and 26 men. The main characteristics of the patients at diagnosis are listed in Table 1. The distribution of patients according to the biological marker-adjusted International Prognostic Index (B-IPI) $[24,25](\mathrm{n}=49)$ was as follows: low risk, 2 cases (4\%); low/intermediate risk, 18 cases (37\%); high/intermediate risk, 12 cases (24\%); and high risk, 17 cases $(35 \%)$.

\section{Clinicopathological significance of p65 expression}

The associations between patient characteristics and p65 expression are shown in Table 2. Of the 49 patients examined, $14(28.6 \%)$ had positive p65 expression. Positive expression of p65 protein showed a trend of correlation with patient age $(\mathrm{p}=0.055)$, but not with other clinicopathologic factors, including sex, disease stage, LDH level, B symptom, and MYC and BCL-2 expression levels. Of the 14 tumor tissues with positive p65 expression, 6 were positive for MYC and 9 were positive for BCL-2.

\section{Survival analysis}

Six patients showed disease progression, whereas 11 patients relapsed during the treatment with $\mathrm{R}-\mathrm{CHOP}$ (Figure 1). For all patients, the 3-year estimated OS was $76.7 \%$, and the PFS was $61.6 \%$. The negative p65 group showed a significantly better survival compared to the positive p65 group in terms of both 3-year estimated OS (91.2\% vs. $39.3 \%, p=0.003)$ and PFS (75.6\% vs. $26.5 \%$, $\mathrm{p}=0.002$ ) (Figure 2). The data for the 49 patients was examined by Cox multivariate analysis, and the B-IPI was proved to be an independent predictor of survival (Table 3). For patients with 4 or more risk factors, the Cox multivariate analysis showed that p65 was an independent prognostic factor of OS (HR 5.99, 95\% CI=1.39-25.75, $\mathrm{p}=0.016)$ and PFS (HR 4.01, 95\%CI=1.15-14.00, $\mathrm{p}=0.029)$ (Figure 3).

\section{DISCUSSION}

DLBCL is an aggressive subtype of non-Hodgkin's lymphoma (NHL) with diverse clinical and molecular characteristics. Currently, the International Prognostic Index is the most successful clinical model for predicting DLBCL outcome. Many efforts have been made to improve this model's discriminatory capabilities [24-30]. Several prognostic models have been built for DLBCL. We have showed that B-IPI, a biomarker-based prognostic model, is a reliable and clinically applicable tool for predicting DLBCL prognosis $[25,26]$.

GEP has shown that a specific subgroup of DLBCL called activated B-cell-like (ABC) DLBCL has constitutive activation of the NF- $\kappa B$ system [31]. Furthermore, abrogation of NF- $\kappa \mathrm{B}$ activity in vitro causes rapid cell death in non-GCB lymphoma cells $[31,32]$. Characterization of DLBCLs with NF$\kappa \mathrm{B}$ activation is of great importance, as it may aid in identifying lymphomas for which NF- $\kappa \mathrm{B}$ can be targeted for therapeutic intervention. Theoretically, treatment with the proteasome inhibitor bortezomib, a potent inhibitor of the transcription and nuclear translocation of $\mathrm{NF}-\kappa \mathrm{B}[33,34]$, may overcome the negative prognosis associated with non-GCB disease in comparison to GCB disease in clinical practice [35, 36]. However, a phase 2 randomized study showed that substituting bortezomib for vincristine in the standard R-CHOP regimen did not significantly improve prognosis in patients with previously untreated, IHCconfirmed non-GCB DLBCL [37]. Subgroup analyses demonstrated no statistically significant differences in baseline IPI score between patients treated with VR-CAP and RCHOP. It is possible that the lack of difference in efficacy between VR-CAP and RCHOP therapies is because $\mathrm{NF}-\kappa \mathrm{B}$ activity only serves as a prognostic factor for the high risk non-GCB subtype of DLBCL (B-IPI scores $\geq 4$ ), which was observed in our study. Bortezomib may be sufficiently active in that lymphoma subtype, which is characterized by constitutive NF- $\kappa \mathrm{B}$ activation and shows resistance to current therapeutic modalities.

The classical NF- $\kappa \mathrm{B}$ activation pathway involves dimerization of p50 and p65 or c-Rel. Those dimers 
Table 1: Clinical features of patients

\begin{tabular}{|c|c|}
\hline Patient Characteristic & Value \\
\hline Number & 49 \\
\hline Median age, y (range) & $59(18-77)$ \\
\hline Male sex $(\%)$ & $26(53)$ \\
\hline \multicolumn{2}{|l|}{ IPI factors } \\
\hline Age > 60 y $(\%)$ & $23(47)$ \\
\hline $\mathrm{ECOG} \geq 2(\%)$ & $10(20)$ \\
\hline Elevated LDH (\%) & $25(51)$ \\
\hline More than 1 extranodal site $(\%)$ & $36(73)$ \\
\hline Stage III/IV (\%) & $34(69)$ \\
\hline \multicolumn{2}{|l|}{ IPI } \\
\hline Low risk $(\%)$ & $5(10)$ \\
\hline Low / intermediate $(\%)$ & $14(29)$ \\
\hline High / intermediate (\%) & 19(39) \\
\hline High risk $(\%)$ & $11(22)$ \\
\hline \multicolumn{2}{|l|}{ Tumor characteristics } \\
\hline High MYC expression (\%) & $25(51)$ \\
\hline High BCL-2 expression (\%) & $29(59)$ \\
\hline MYC and BCL-2 coexpression (\%) & $18(37)$ \\
\hline \multicolumn{2}{|l|}{ B-IPI } \\
\hline Low risk $(\%)$ & $2(4)$ \\
\hline Low / intermediate $(\%)$ & $18(37)$ \\
\hline High / intermediate (\%) & $12(24)$ \\
\hline High risk $(\%)$ & $17(35)$ \\
\hline
\end{tabular}

are held inactive in the cytoplasm by specific inhibitors known as the inhibitor of $\kappa \mathrm{B}(\mathrm{I} \kappa \mathrm{B})$ protein $[22]$. I $\mathrm{B}$

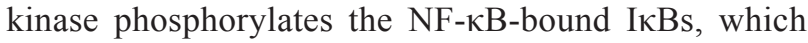
targets the I $\mathrm{B} B \mathrm{~s}$ for ubiquitin-dependent degradation and allows the p65/p50 complex to translocate to the nucleus and initiate transcription of target genes [22] The p65/p50 pathway has been shown to promote inflammation, cell proliferation, and cell survival through the production of several inhibitors of apoptotic signaling and to contribute to angiogenesis, tumor promotion and metastasis [22]. Nuclear expression of NF- $\kappa \mathrm{B}$ has been reported in various tumor types and is considered a sign of NF- $\kappa \mathrm{B}$ activation.

Our previous study showed that addition of MYC and BCL-2 to the IPI may allow its outcome prediction to be more clinically relevant. MYC overexpression sensitizes cells to NF- $\mathrm{BB}$-mediated apoptosis, and a persistent lack of $\mathrm{NF}-\kappa \mathrm{B}$ signaling is a prerequisite for MYC-mediated tumorigenesis [38]. The NF-кB activation pathway was found to be constitutively active, inducing the expression of anti-apoptotic genes, such as BCL-2 and inhibiting the action of pro-apoptotic (Bax and Bak) proteins to promote cell survival [39]. Offner et al recognized that evaluation of MYC and BCL- 2 expression in a phase 2 randomized study may provide further insight into the results of previous studies; however, such analyses were precluded by the lack of sample availability [37]. Here, a positive correlation between MYC, BCL-2 and p65 was not found. This was a retrospective study with a small number of patients; therefore, the patient cohort may not be representative of the general population of non-GCB DLBCL patients.

Our study showed that p65 is an independent predictor of survival in high risk non-GCB DLBCL. Further exploration is required to better clarify the role of the NF- $\mathrm{NB}$ 
Table 2: The relationship between p65 expressions and clinicopathologic parameters

\begin{tabular}{|c|c|c|c|c|c|}
\hline \multirow[t]{2}{*}{ Clinicopathologic parameters } & \multirow[t]{2}{*}{$\mathbf{N}$} & \multicolumn{2}{|c|}{ P65 } & \multirow[t]{2}{*}{$\chi^{2}$} & \multirow[t]{2}{*}{$p^{\mathrm{a}}$} \\
\hline & & $\begin{array}{c}+ \\
(n=14)\end{array}$ & $\begin{array}{c}- \\
(n=35)\end{array}$ & & \\
\hline \multicolumn{6}{|l|}{ Sex } \\
\hline Male & 26 & 7 & 19 & \multirow{2}{*}{0.074} & \multirow{2}{*}{1.000} \\
\hline Female & 23 & 7 & 16 & & \\
\hline \multicolumn{6}{|l|}{ Age,years } \\
\hline$<60$ & 26 & 4 & 22 & \multirow{2}{*}{4.720} & \multirow{2}{*}{0.055} \\
\hline$>60$ & 23 & 10 & 13 & & \\
\hline \multicolumn{6}{|l|}{ Stage } \\
\hline I-II & 15 & 2 & 13 & \multirow{2}{*}{2.460} & \multirow{2}{*}{0.174} \\
\hline III-IV & 34 & 12 & 22 & & \\
\hline \multicolumn{6}{|l|}{ B symptom } \\
\hline Yes & 23 & 8 & 15 & \multirow{2}{*}{0.819} & \multirow{2}{*}{0.528} \\
\hline No & 26 & 6 & 20 & & \\
\hline \multicolumn{6}{|l|}{ ECOG } \\
\hline $0-1$ & 39 & 9 & 30 & \multirow{2}{*}{2.827} & \multirow{2}{*}{0.124} \\
\hline $2-4$ & 10 & 5 & 5 & & \\
\hline \multicolumn{6}{|l|}{ LDH } \\
\hline Normal & 24 & 6 & 18 & \multirow{2}{*}{0.294} & \multirow{2}{*}{0.754} \\
\hline High & 25 & 8 & 17 & & \\
\hline \multicolumn{6}{|l|}{ MYC } \\
\hline Low & 24 & 8 & 16 & \multirow{2}{*}{0.523} & \multirow{2}{*}{0.538} \\
\hline High & 25 & 6 & 19 & & \\
\hline \multicolumn{6}{|l|}{ BCL-2 } \\
\hline Low & 20 & 5 & 15 & \multirow{2}{*}{0.211} & \multirow{2}{*}{0.754} \\
\hline High & 29 & 9 & 20 & & \\
\hline MYC and BCL-2 coexpression & & & & & \\
\hline Yes & 18 & 5 & 13 & 0000 & 1000 \\
\hline No & 31 & 9 & 22 & 0.009 & 1.000 \\
\hline IPI Scores & & & & & \\
\hline $0-2$ & 19 & 3 & 16 & 2401 & 010 \\
\hline $3-5$ & 30 & 11 & 19 & 2.404 & 0.194 \\
\hline B-IPI Scores & & & & & \\
\hline $0-3$ & 20 & 4 & 16 & 1017 & 024 \\
\hline $4-7$ & 29 & 10 & 19 & 1.217 & 0.344 \\
\hline
\end{tabular}

pathway and, in particular, determine the subgroup of nonGCB DLBCL for which the pathway will serve as a valuable therapeutic target. When that information is gained, the combined therapeutic approach obtained by blocking NF- $\kappa B$ and inducing the apoptotic response may result in the most favorable outcome possible for non-GCB DLBCL patients. 


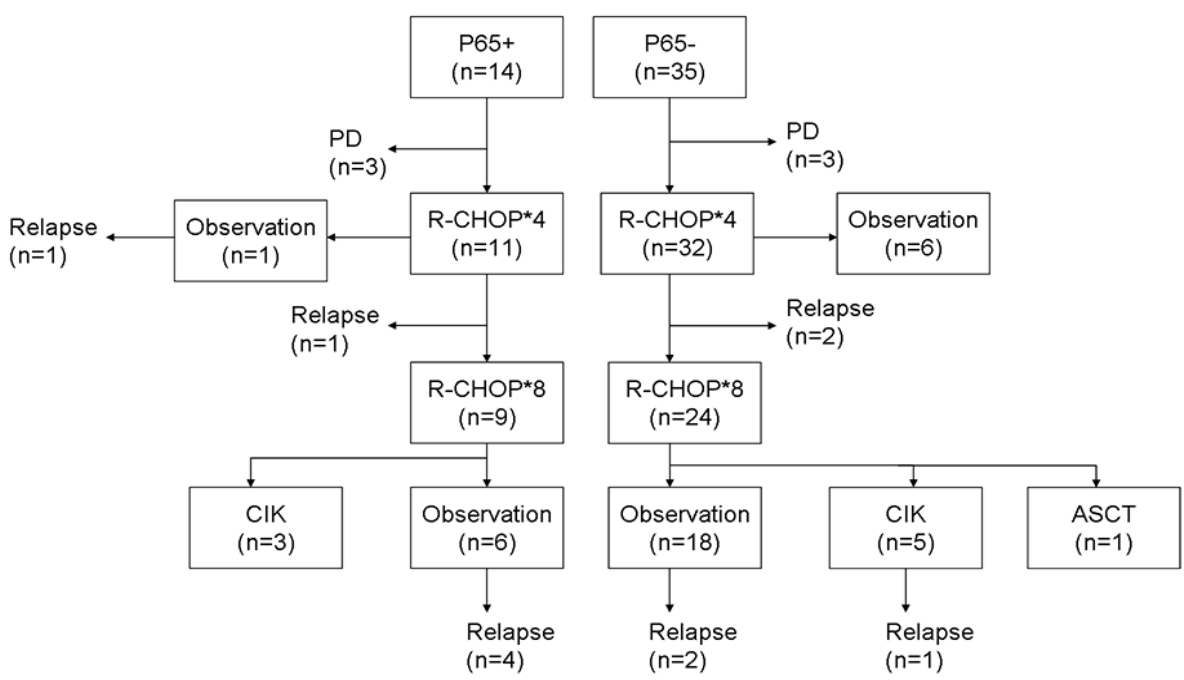

Figure 1: Summary of the treatments and responses. ASCT autologous stem cell transplantation, CIK cytokine-induced killer cells, PD progressive disease.
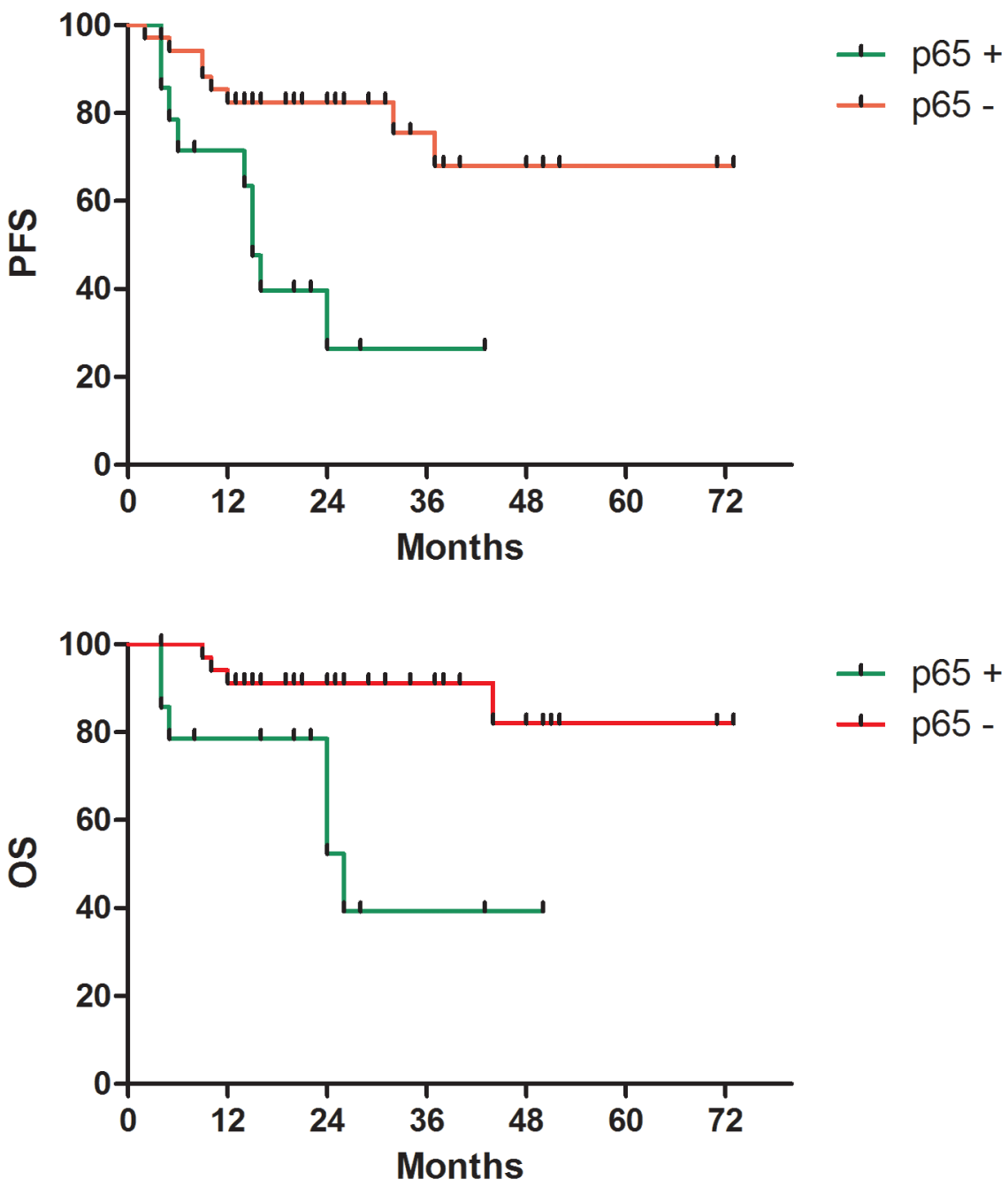

Figure 2: Survival according to $\mathbf{p} 65$ protein expression. A. Progression-free survival $(\mathrm{p}=0.002)$. B. Overall survival ( $\mathrm{p}=0.003)$. 
Table 3: Survival analysis in patients with non-GCB DLBCL

\begin{tabular}{cccccc}
\hline & Parameter & \multicolumn{2}{c}{ Univariate analysis } & \multicolumn{2}{c}{ Multivariate analysis } \\
\cline { 3 - 5 } & & HR(95\%CI) & $\boldsymbol{p}$ & HR(95\%CI) & $\boldsymbol{P}$ \\
\hline \multirow{4}{*}{ PFS } & $3.75(1.17-12.04)$ & 0.026 & $1.59(0.91-2.77)$ & 0.854 \\
& IPI & $3.92(1.23-12.48)$ & 0.021 & $2.26(1.13-3.88)$ & 0.003 \\
& B-IPI & $4.17(1.19-14.66)$ & 0.026 & $2.14(0.49-9.34)$ & 0.306 \\
& BCL-2 & $2.27(0.87-5.94)$ & 0.093 & $1.00(0.32-3.16)$ & 0.595 \\
MYC and BCL-2 & $4.11(1.55-10.91)$ & 0.004 & $4.85(1.74-13.51)$ & 0.003 \\
& P65 & $5.99(2.09-17.8)$ & 0.001 & $3.62(0.97-10.69)$ & 0.796 \\
& IPI & $9.15(1.64-50.93)$ & 0.011 & $8.13(1.47-44.76)$ & 0.016 \\
& B-IPI & $6.39(0.81-50.49)$ & 0.079 & $1.23(0.95-14.31)$ & 0.872 \\
BCL-2 & $4.08(1.05-15.79)$ & 0.042 & $2.27(0.46-11.15)$ & 0.974 \\
& MYC and BCL-2 & $4.50(1.51-19.92)$ & 0.009 & $4.02(1.00-16.19)$ & 0.050 \\
\hline
\end{tabular}

B-IPI Scores 4-7

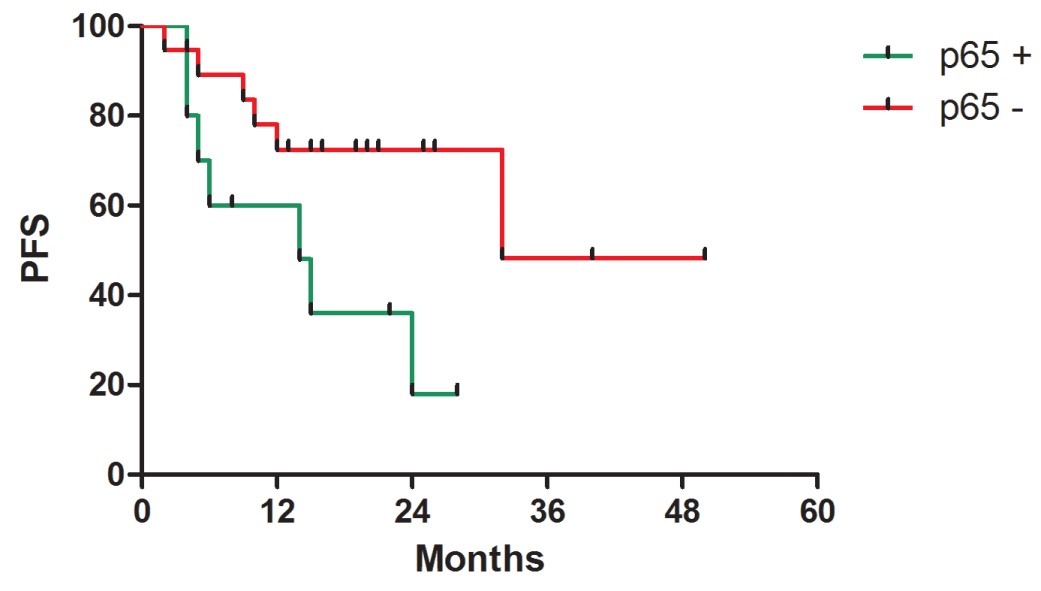

B-IPI Scores 4-7

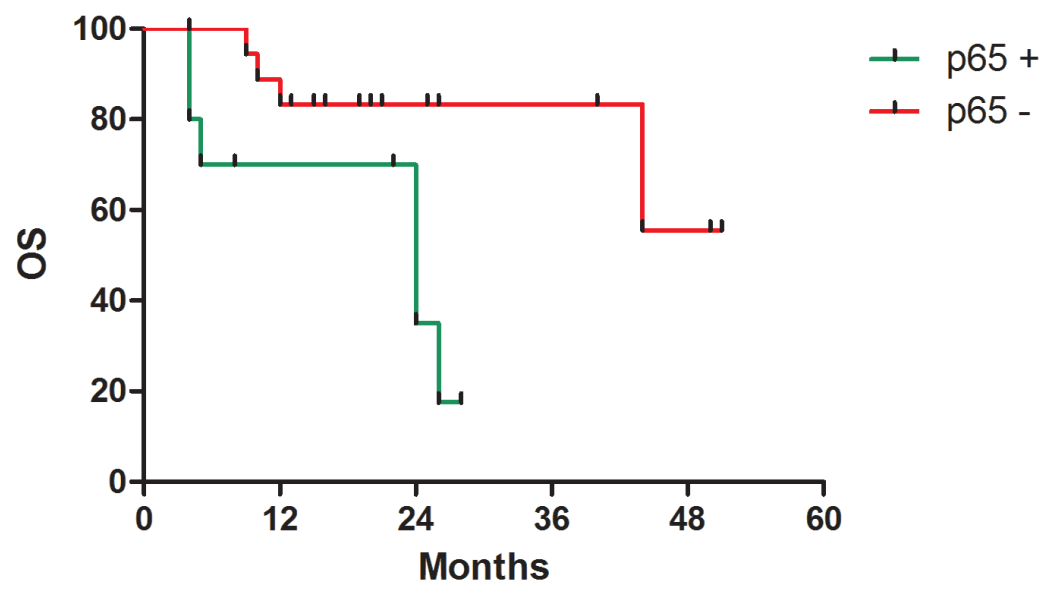

Figure 3: Survival according to 65 protein expression in patients with 4 or more than 4 risk factors. A. Progression-free survival $(\mathrm{p}=0.016)$. B. Overall survival $(\mathrm{p}=0.029)$. 


\section{MATERIALS AND METHODS}

\section{Patients and treatments}

We retrospectively studied 49 patients with de novo non-GCB DLBCL centrally confirmed by the Hans method [9] who were treated at the Nanjing Drum Tower Hospital from 2008 to 2014. The study cohort included 26 males and 23 females with an average age of 59 years (range 18-77 years). All patients enrolled were in treatment with 4 to 8 cycles of the R-CHOP regimen at 21-day intervals. The patients underwent (18)F-FDG PET/ $\mathrm{CT}$ before starting on R-CHOP treatment, after cycle four of the treatment, and after completion of it. Some patients only received 4 cycles of the R-CHOP regimen because of economic reasons. This study was approved by the institutional review board, and all patients gave written informed consent.

\section{Immunohistochemistry}

Formalin-fixed, paraffin-embedded tissue (FFPE) sections of $3 \mu \mathrm{m}$ in thickness were placed on adhesivecoated slides. Heated antigen retrieval was performed by immersing the slides in EDTA buffer ( $\mathrm{pH}$ 8.0) and heating them for $2 \mathrm{~min}$ in a steamer. An antibody against p65 (Beijing Zhongshan Golden Bridge Biotechnology Co. Ltd, dilution 1:100) was used in addition to an autostainer following the standard polymer method (Dako Autostainer Plus). MYC and BCL-2 staining was completed as we previously reported [24-26]. Immunohistochemistry was evaluated by 2 experienced hematopathologists using a multihead microscope. MYC immunostaining was scored as positive when $50 \%$ of the tumor cells had nuclear staining [24-26]. Expression of BCL-2 was evaluated with cytoplasmic staining, staining $30 \%$ was considered as positive $[25,26]$. Expression of p65 was considered positive when $50 \%$ or more of the nuclei of the tumor cells were stained $[40,41]$.

\section{Statistical analysis}

Overall survival (OS) was computed from the date of diagnosis to the date of either death or last documented follow-up. Progression-free survival (PFS) was calculated from the date of diagnosis to either progression or death from any cause. PFS and OS rates were estimated using the Kaplan-Meier method, and differences were assessed by the log-rank (Mantel-Cox) test. Cox multivariate analysis was performed to test the prognostic value of the factors. Hazard ratios (HR) and their 95\% confidence intervals (CI) were also calculated. Associations between p65 expression and the clinical characteristics of the patients were described by the Chi-square test. Fisher's exact test was also used when necessary. All data were statistically analyzed using a commercially available statistical software package (SPSS 19.0; IBM Corp., Armonk, NY, USA). All tests were bilateral, and $P$-value $<0.05$ was considered statistically significant.

\section{Abbreviations}

COO, cell of origin; DLBCL, diffuse large B-cell lymphoma; FFPE, formalin-fixed, paraffinembedded tissue; GEP, gene expression profiling; GCB, germinal center B-cell; HR, hazard ratios; IHC, immunohistochemistry; PFS, progression-free survival; OS, overall survival.

\section{CONFLICTS OF INTEREST}

\section{None.}

\section{GRANT SUPPORT}

Jiangsu Provincial Special Program of Medical Science, BL2012005.

Medical Science and Technology Key Project of Nanjing, ZKX14015.

Peak of Six Talent in Jiangsu Province, 2014-WSN049.

Medical Foundation of Nanjing Health and Family Planning Commission, YKK15068.

\section{Author contributions}

All authors contributed toward data analysis, drafting and revising the paper and agree to be accountable for all aspects of the work.

\section{REFERENCES}

1. Cultrera JL and Dalia SM. Diffuse large B-cell lymphoma: current strategies and future directions. Cancer Control. 2012; 19:204-13.

2. Wright G, Tan B, Rosenwald A, Hurt EH, Wiestner A and Staudt LM. A gene expression-based method to diagnose clinically distinct subgroups of diffuse large B cell lymphoma. Proc Natl Acad Sci U S A. 2003; 100:9991-6.

3. Bea S, Zettl A, Wright G, Salaverria I, Jehn P, Moreno V, Burek C, Ott G, Puig X, Yang L, Lopez-Guillermo A, Chan WC, Greiner TC, et al. Diffuse large B-cell lymphoma subgroups have distinct genetic profiles that influence tumor biology and improve gene-expression-based survival prediction. Blood. 2005; 106:3183-90.

4. Rosenwald A, Wright G, Chan WC, Connors JM, Campo E, Fisher RI, Gascoyne RD, Muller-Hermelink HK, Smeland EB, Giltnane JM, Hurt EM, Zhao H, Averett L, et al. The use of molecular profiling to predict survival after chemotherapy for diffuse large-B-cell lymphoma. N Engl J Med. 2002; 346:1937-47. 
5. Shipp MA, Ross KN, Tamayo P, Weng AP, Kutok JL, Aguiar RC, Gaasenbeek M, Angelo M, Reich M, Pinkus GS, Ray TS, Koval MA, Last KW, et al. Diffuse large B-cell lymphoma outcome prediction by gene-expression profiling and supervised machine learning. Nat Med. 2002; 8:68-74.

6. Lossos IS. Molecular pathogenesis of diffuse large B-cell lymphoma. J Clin Oncol. 2005; 23:6351-7.

7. Lenz G, Wright G, Dave SS, Xiao W, Powell J, Zhao H, Xu W, Tan B, Goldschmidt N, Iqbal J, Vose J, Bast M, Fu K, et al. Stromal gene signatures in large-B-cell lymphomas. N Engl J Med. 2008; 359:2313-23.

8. Alizadeh AA, Eisen MB, Davis RE, Ma C, Lossos IS, Rosenwald A, Boldrick JC, Sabet H, Tran T, Yu X, Powell JI, Yang L, Marti GE, et al. Distinct types of diffuse large B-cell lymphoma identified by gene expression profiling. Nature. 2000; 403:503-11.

9. Hans CP, Weisenburger DD, Greiner TC, Gascoyne RD, Delabie J, Ott G, Mü ller-Hermelink HK, Campo E, Braziel RM, Jaffe ES, Pan Z, Farinha P, Smith LM, et al. Confirmation of the molecular classification of diffuse large B-cell lymphoma by immunohistochemistry using a tissue microarray. Blood. 2004; 103:275-82.

10. Choi WW, Weisenburger DD, Greiner TC, Piris MA, Banham AH, Delabie J, Braziel RM, Geng H, Iqbal J, Lenz G, Vose JM, Hans CP, Fu K, et al. A new immunostain algorithm classifies diffuse large B-cell lymphoma into molecular subtypes with high accuracy. Clin Cancer Res. 2009; 15:5494-502.

11. Meyer PN, Fu K, Greiner TC, Smith LM, Delabie J, Gascoyne RD, Ott G, Rosenwald A, Braziel RM, Campo E, Vose JM, Lenz G, Staudt LM, et al. Immunohistochemical methods for predicting cell of origin and survival in patients with diffuse large B-cell lymphoma treated with rituximab. J Clin Oncol. 2011; 29:200-7.

12. National Comprehensive Cancer Network (NCCN). NCCN Clinical Practice Guidelines in Clinical Oncology (NCCN Guidelines). Non-Hodgkin's Lymphomas. 2015.

13. Fu K, Weisenburger DD, Choi WW, Perry KD, Smith LM, Shi X, Hans CP, Greiner TC, Bierman PJ, Bociek RG, Armitage JO, Chan WC and Vose JM. Addition of rituximab to standard chemotherapy improves the survival of both the germinal center B-cell-like and non-germinal center B-celllike subtypes of diffuse large B-cell lymphoma. J Clin Oncol. 2008; 26:4587-94.

14. Malumbres R, Chen J, Tibshirani R, Johnson NA, Sehn LH, Natkunam Y, Briones J, Advani R, Connors JM, Byrne GE, Levy R, Gascoyne RD and Lossos IS. Paraffin-based 6-gene model predicts outcome in diffuse large B-cell lymphoma patients treated with R-CHOP. Blood. 2008; 111:5509-14.

15. Natkunam Y, Farinha P, Hsi ED, Hans CP, Tibshirani R, Sehn LH, Connors JM, Gratzinger D, Rosado M, Zhao S, Pohlman B, Wongchaowart N, Bast M, et al. LMO2 protein expression predicts survival in patients with diffuse large B-cell lymphoma treated with anthracycline-based chemotherapy with and without rituximab. J Clin Oncol. 2008; 26:447-54.

16. Rimsza LM, Leblanc ML, Unger JM, Miller TP, Grogan TM, Persky DO, Martel RR, Sabalos CM, Seligmann B, Braziel RM, Campo E, Rosenwald A, Connors JM, et al. Gene expression predicts overall survival in paraffinembedded tissues of diffuse large B-cell lymphoma treated with R-CHOP. Blood. 2008; 112:3425-33.

17. Li Q and Verma IM. NF-kappaB regulation in the immune system. Nat Rev Immunol. 2002; 2:725-34.

18. Siebenlist U, Brown $\mathrm{K}$ and Claudio E. Control of lymphocyte development by nuclear factor-kappaB. Nat Rev Immunol. 2005; 5:435-45.

19. Hailfinger S, Lenz G, Ngo V, Posvitz-Fejfar A, Rebeaud F, Guzzardi M, Penas EM, Dierlamm J, Chan WC, Staudt LM and Thome M. Essential role of MALT1 protease activity in activated B cell-like diffuse large B-cell lymphoma. Proc Natl Acad Sci U S A. 2009; 106:19946-51.

20. Lam LT, Wright G, Davis RE, Lenz G, Farinha P, Dang L, Chan JW, Rosenwald A, Gascoyne RD and Staudt LM. Cooperative signaling through the signal transducer and activator of transcription 3 and nuclear factor- $\{$ kappa $\} \mathrm{B}$ pathways in subtypes of diffuse large B-cell lymphoma. Blood. 2008; 111:3701-13.

21. Pavan A, Spina M, Canzonieri V, Sansonno S, Toffoli G and De Re V. Recent prognostic factors in diffuse large B-cell lymphoma indicate NF-kappaB pathway as a target for new therapeutic strategies. Leuk Lymphoma. 2008; 49:2048-58.

22. Gasparini C, Celeghini C, Monasta L and Zauli G. NF- $\kappa$ B pathways in hematological malignancies. Cell Mol Life Sci. 2014; 71:2083-102.

23. O'Shea JM and Perkins ND. Regulation of the RelA (p65) transactivation domain. Biochem Soc Trans. 2008; 36:603-8.

24. Zhou M, Wang J, Ouyang J, Xu JY, Chen B, Zhang QG, Zhou RF, Yang YG, Shao XY, Xu Y, Chen YM, Fan XS and Wu HY. MYC protein expression is associated with poor prognosis in diffuse large B cell lymphoma patients treated with RCHOP chemotherapy. Tumour Biol. 2014; 35:6757-62.

25. Wang J, Zhou M, Xu JY, Chen B and Ouyang J. MYC and BCL-2 adjusted-International Prognostic Index (A-IPI) is a better predictor of outcome than the standard IPI for patients with diffuse large B-cell lymphoma treated with R-CHOP. Histol Histopathol. 31:285-92.

26. Wang J, Zhou M, Xu JY, Chen B and Ouyang J. Combination of $\mathrm{Bcl}-2$ and MYC protein expression improves high-risk stratification in diffuse large B-cell lymphoma. Onco Targets Ther 2015; 8:2645-2650.

27. Sehn LH, Berry B, Chhanabhai M, Fitzgerald C, Gill K, Hoskins P, Klasa R, Savage KJ, Shenkier T, Sutherland J, Gascoyne RD and Connors JM. The revised International Prognostic Index (R-IPI) is a better predictor of outcome than the standard IPI for patients with diffuse large B-cell lymphoma treated with R-CHOP. Blood. 2007; 109:1857-61. 
28. Advani RH, Chen H, Habermann TM, Morrison VA, Weller EA, Fisher RI, Peterson BA, Gascoyne RD and Horning SJ; Eastern Cooperative Oncology Group; Cancer and Leukemia Group B; Southwest Oncology Group. Comparison of conventional prognostic indices in patients older than 60 years with diffuse large B-cell lymphoma treated with R-CHOP in the US Intergroup Study (ECOG 4494, CALGB 9793): consideration of age greater than 70 years in an elderly prognostic index (E-IPI). Br J Haematol. 2010; 151:143-151.

29. Zhou Z, Sehn LH, Rademaker AW, Gordon LI, Lacasce AS, Crosby-Thompson A, Vanderplas A, Zelenetz AD, Abel GA, Rodriguez MA, Nademanee A, Kaminski MS, Czuczman MS, et al. An enhanced International Prognostic Index (NCCN-IPI) for patients with diffuse large B-cell lymphoma treated in the rituximab era. Blood. 2014; $123: 837-42$.

30. Cox MC, Nofroni I, Ruco L, Amodeo R, Ferrari A, La Verde G, Cardelli P, Montefusco E, Conte E, Monarca B and Aloe-Spiriti MA. Low absolute lymphocyte count is a poor prognostic factor in diffuse-large-B-cell-lymphoma. Leuk Lymphoma. 2008; 49:1745-51.

31. Davis RE, Brown KD, Siebenlist $U$ and Staudt LM. Constitutive nuclear factor kappaB activity is required for survival of activated B cell-like diffuse large B cell lymphoma cells. J Exp Med. 2001; 194:1861-74.

32. Lam LT, Davis RE, Pierce J, Hepperle M, Xu Y, Hottelet M, Nong Y, Wen D, Adams J, Dang L and Staudt LM. Small molecule inhibitors of IkappaB kinase are selectively toxic for subgroups of diffuse large B-cell lymphoma defined by gene expression profiling. Clin Cancer Res. 2005; 11:28-40.

33. Allen C, Saigal K, Nottingham L, Arun P, Chen Z and Van Waes C. Bortezomib-induced apoptosis with limited clinical response is accompanied by inhibition of canonical but not alternative nuclear factor- $\{$ kappa $\} B$ subunits in head and neck cancer. Clin Cancer Res. 2008; 14:4175-85.

34. Bu R, Hussain AR, Al-Obaisi KA, Ahmed M, Uddin S and Al-Kuraya KS. Bortezomib inhibits proteasomal degradation of $\mathrm{I} \kappa \mathrm{B} \alpha$ and induces mitochondrial dependent apoptosis in activated B-cell diffuse large B-cell lymphoma. Leuk Lymphoma. 2014; 55:415-24.

35. Dunleavy K, Pittaluga S, Czuczman MS, Dave SS, Wright G, Grant N, Shovlin M, Jaffe ES, Janik JE, Staudt LM and Wilson WH. Differential efficacy of bortezomib plus chemotherapy within molecular subtypes of diffuse large B-cell lymphoma. Blood. 2009; 113:6069-76.

36. Ruan J, Martin P, Furman RR, Lee SM, Cheung K, Vose JM, Lacasce A, Morrison J, Elstrom R, Ely S, Chadburn A, Cesarman E, Coleman M, et al. Bortezomib plus CHOPrituximab for previously untreated diffuse large B-cell lymphoma and mantle cell lymphoma. J Clin Oncol. 2011; 29:690-7.

37. Offner F, Samoilova O, Osmanov E, Eom HS, Topp MS, Raposo J, Pavlov V, Ricci D, Chaturvedi S, Zhu E, van de Velde H, Enny C, Rizo A, et al. Frontline rituximab, cyclophosphamide, doxorubicin, and prednisone with bortezomib (VR-CAP) or vincristine (R-CHOP) for non-GCB DLBCL. Blood. 2015 Jul 31. pii: blood-2015-03-632430.

38. Klapproth K, Sander S, Marinkovic D, Baumann B and Wirth T. The IKK2/NF- $\{$ kappa $\}$ B pathway suppresses MYC-induced lymphomagenesis. Blood. 2009; 114:2448-58.

39. Cormier F, Monjanel H, Fabre C, Billot K, Sapharikas E, Chereau F, Bordereaux D, Molina TJ, Avet-Loiseau $\mathrm{H}$ and Baud V. Frequent engagement of RelB activation is critical for cell survival in multiple myeloma. PLoS One. 2013; 8:e59127.

40. Hu CR, Wang JH, Wang R, Sun Q and Chen LB. Both FOXP1 and p65 expression are adverse risk factors in diffuse large B-cell lymphoma: a retrospective study in China. Acta Histochem. 2013; 115:137-43.

41. Espinosa I, Briones J, Bordes R, Brunet S, Martino R, Sureda A, Sierra J and Prat J. Activation of the NF-kappaB signalling pathway in diffuse large B-cell lymphoma: clinical implications. Histopathology. 2008; 53:441-9. 